\title{
Upaya Meningkatkan Keberhasilan UMKM yang Dikelola Oleh Wanita melalui Variabel Kontekstual
}

\author{
Novie Noordiana Rachma Yulia ${ }^{1}$, Wilsna Rupilu \\ Universitas Teknologi Surabaya ${ }^{1,2}$
}

\begin{abstract}
Poverty and unemployment have become a problem in several developing countries, including Indonesia. One of the roles of SMEs in supporting the Indonesian economy is to reduce poverty through providing employment. Women's participation in the business sector has also increased, this phenomenon occurs throughout the world, including in Indonesia, as shown by USAID and IFC in the Market Research Study in 2016. This study aims to determine whether the factors in the form of access to capital, government support, social networking, competitive advantage and strategic market position, consumer orientation, business plans, marketing communications, and women's personality influence the success of women-owned SMEs, with the hope that this can be a motivation for Indonesian women for becoming more productive and having an entrepreneurial spirit. Data was taken from 400 respondents in 8 sub-districts in Surabaya, then processed using SPSS program. The results of this study showed that simultaneously the independent variables consist of Access to capital, Government Support, Social Networks, Competitive Advantages and Positioning, Consumer Orientation, Business Plans, Marketing Communications, and Women's strengths have a significant influence on the success of women-owned SMEs. While the results of the t test showed that partially the Social Network with an observation $t$ value of 2.546, Business Plan with an observation $t$ value of 4, 797, and finally the Advantages of Women with an observation $t$ value of 8.768 affected the success of women-owned SMEs.
\end{abstract}

Keywords: SMEs, Consumer Orientation, Business Plan, Competitif Advantage.

\section{Pendahuluan}

Kemiskinan dan pengangguran telah menjadi masalah di beberapa Negara berkembang, termasuk di Indonesia. Pada 2004, pengangguran mencapai 10,14\% dari populasi atau sekitar 10,25 juta jiwa. Tahun 2005, setelah harga minyak dunia melonjak di atas US $\$ 50$ per barel pada Oktober 2005, Indonesia mengalami imbasnya dan angka kemiskinan naik menjadi 10,30\% atau 10,85 juta. Pada 2006 angka tersebut meningkat kembali menjadi $10,40 \%$ atau sekitar 11,1 juta. Pada 
2007 perekonomian relatif lebih sehat sehungga pengangguran dapat diturunkan menjadi 9,75\% tapi jumlahnya juga masih besar, yaitu 10,55 juta. Jumlah tersebut merupakan pengangguran terbuka.

Salah satu peranan UMKM dalam mendukung perekonomian Indoneia adalah dengan mengurangi tingkat kemiskinan melalui penyediaan lapangan kerja. Pada saat terjadi krisis ekonomi 1997, sektor usaha yang mempunyai daya tahan relatif besar adalah sektor UMKM. Data Badan Pusat Statistik memperlihatkan, pasca krisis ekonomi tahun 1997-1998 jumlah UMKM tidak berkurang, justru meningkat terus, bahkan mampu menyerap 85 juta hingga 107 juta tenaga kerja sampai tahun 2012. Pada tahun itu, jumlah pengusaha di Indonesia sebanyak 56.539.560 unit. Dari jumlah tersebut, UMKM sebanyak 56.534.592 unit atau 99.99\%. Sisanya, sekitar 0,01\% atau 4.968 unit adalah usaha besar (BI, 2015).

Demikian juga survei yang dilakukan oleh Departemen Koperasi dan PKM (1999). Dalam survei tersebut diketahui bahwa dari 225.000 UMKM yang teridentifikasi, sebanyak 64,1\% UMKM yang masih bertahan, 0,9\% mampu berkembang, $31 \%$ mengurangi usaha, dan hanya $4 \%$ saja yang terpaksa menghentikan usahanya. Hal ini membuktikan bahwa UMKM mempunyai daya tahan yang lebih lentur terhadap krisis ekonomi (dalam Kimbal, 2015).

Bahkan sejak 2008-2013 menunjukkan perkembangan yang menggembirakan seperti terlihat pada Tabel 1 berikut ini:

Tabel 1. Jumlah Unit UMKM

\begin{tabular}{|l|l|}
\hline \multicolumn{1}{|c|}{ Tahun } & Unit \\
\hline 2008 & 51.409 .612 \\
\hline 2009 & 52.764 .603 \\
\hline 2010 & 53.823 .732 \\
\hline 2011 & 55.206 .444 \\
\hline 2012 & 56.534 .592 \\
\hline 2013 & 57.895 .721 \\
\hline
\end{tabular}

Sumber: BPS, 2016

Dari tabel di atas terlihat bahwa UMKM Indonesia secara makro mengalami pertumbuhan cukup baik. 
UMKM Indonesia memiliki peranan yang sangat potensial dalam perekonomian nasional. Walaupun demikian, kenyataannya masih banyak masalah menghadang dalam pengembangannya. Meningkatnya persaingan bisnis, khususnya persaingan melawan pesaing besar dan modern, membuat UMKM berada di posisi yang rentan (mudah diserang). Di Indonesia, sebagian besar UMKM beroperasi dengan cara tradisional dalam hal produksi dan pemasaran. Kurangnya modal, keahlian, dan masalah dalam pengembangan bisnis merupakan masalah-masalah yang dihadapi UMKM di Indonesia (Kementrian KUMKM dan BPS, 2004).

Di sisi lain meningkatnya partisipasi wanita dalam sektor bisnis adalah sebuah fenomena yang terjadi di seluruh dunia, termasuk di Indonesia. Data pasti jumlah pelaku UMKM wanita di Indonesia belum ada, tetapi sebagai ilustrasi, sejak berdirinya pada 10 Februari 1975 hingga saat ini, Ikatan Wanita Pengusaha Indonesia (IWAPI) telah memiliki 30.000 anggota yang tersebar di seluruh propinsi di Indonesia. Dari jumlah tersebut, sebagian besar merupakan pengusaha kecil dan menengah (97\%) dan hanya 3\% yang merupakan pengusaha besar (http://www.iwapi.or.id). Data lain juga ditunjukkan oleh USAID dan IFC dalam Market Research Study pada tahun 2016. “Women-owned businesses make up more than half of all small enterprises and about a third of medium-sized enterprises, thus contributing to economic growth and job creation as much as men-owned SMEs do. Though weaker business metrics are often attributed to women-owned enterprises, their performance is not lower than that of men-owned SMEs: Their business outlook is similar to men-owned SMEs and more women-owned SMEs than men-owned SMEs say that their business is very profitable."

Penelitian ini ditujukan untuk mengetahui apakah faktor-faktor berupa akses kepada modal, dukungan pemerintah, jaringan sosial, keunggulan bersaing dan posisi pasar strategis, orientasi pada konsumen, rencana bisnis, komunikasi pemasaran, dan kepribadian wanita berpengaruh terhadap keberhasilan UMKM yang dikelola oleh wanita, dengan harapan dapat menjadi motivasi bagi wanita Indonesia agar lebih produktif dan semangat berwirausaha. 


\section{Tinjauan Pustaka}

\subsection{Teori tentang pertumbuhan dan perkembangan UKM}

Leigh et.al (1990) mengemukakan beberapa faktor yang berpengaruh terhadap Usaha Kecil Menengah (UKM) adalah:

1. Strategi produk yang sukses.

2. Kemampuan para manajer untuk menciptakan dan mengeksploitasi peluang pasar yang ada dan mengatasi kesulitan-kesulitan yang muncul.

3. Diferensiasi usaha yang fokus, tidak terlalu berkompetisi pada harga, tapi bukan berarti perusahaan mengabaikan faktor harga, tapi lebih pada penekanan bahwa harga bukan merupakan faktor dimana perusahaan menjadikannya sebagai suatu keunggulan bersaing di pasar.

Pemasaran dan penjualan menjadi masalah yang pelik bagi perusahaanperusahaan dengan turn-over yang kecil. Kegagalan usaha banyak disebabkan oleh konsep bisnis yang lemah dan tidak terdefinisi dengan jelas (kurang fokus), pemilik dan pengelola yang kurang terampil dan kurang berkomitmen terhadap usaha yang dijalankan. (Smallbone, 1991)

Aplikasi teori pemasaran relevan untuk diterapkan pada UKM, bahkan dapat membantu mengembangkan UKM, yang perlu diperhatikan adalah penerapan pada UKM akan berbeda dengan penerapan pada perusahaan besar karena sifat UKM yang berbeda. (Sandra et.al, 1996)

Stanworth\&Gray (1991) menyatakan bahwa pada UKM satu orang (biasanya sang pemilik) secara langsung terlibat pada setiap keputusan dari yang paling kecil, seperti mengurus masalah keuangan harian hingga yang paling rumit. Pada UKM sang pemilik juga harus berpandangan luas karena pada saat bersamaan harus memikirkan kemana usahanya akan dibawa dan bagaimana mengurus kegiatan operasional harian.

Storey (1994) mengidentifikasi kompone kunci yang penting dalam menganalisis pertumbuhan UKM, yaitu: karakteristik wirausahawan, karakteristik UKM itu sendiri, dan tipe strategi yang berhubungan dengan pertumbuhan. Berkaitan dengan komponen yang terakhir, peneliti mengeksplor elemen kontekstual dalam perkembangan UKM dan karena UKM yang menjadi obyek 
penelitian merupakan UKM yang dikelola oleh wanita, maka peneliti juga menambahkan faktor yang menjadi kelebihan wanita dibandingkan dengan pria. Penjelasan masing-masing variabel yang terdapat pada model penelitian, seperti yang ditunjukkan pada gambar 1, akan dijelaskan pada bagian berikutnya.

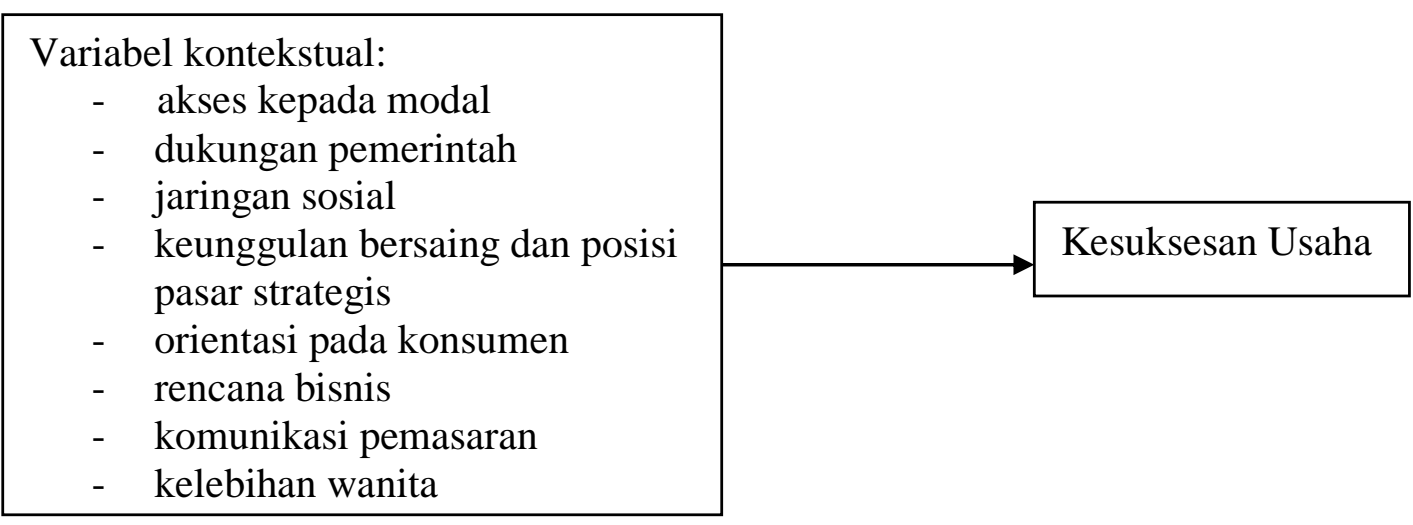

Gambar 1. Model Penelitian

\subsection{Variabel Kontekstual}

\subsubsection{Akses kepada modal.}

Akses modal sudah jelas merupakan salah satu hambatan khas saat memulai bisnis baru. Sumber modal yang potensial dapat berupa tabungan pribadi atau pinjaman dari keluarga, teman, bank atau institusi keuangan lainnya. Kekurangan modal juga merupakan masalah yang dihadapi oleh UKM di Indonesia (Kementrian KUKM dan BPS, 2004).

\subsubsection{Dukungan Pemerintah}

Pemerintah Indonesia melalui Kementrian Koperasi dan UKM telah mengeluarkan banyak program (misalnya pemberian bantuan keuangan) bagi pengembangan UKM (Kementrian KUKM, 2003). Program tersebut terbukti signifikan dalam perkembangan UKM di Indonesia (Kementrian KUKM dan BPS, 2004). Singkatnya, dukungan pemerintah merupakan faktor yang penting untuk mendorong perkembangan UKM.

\subsubsection{Jaringan Sosial}

Jaringan sosial memiliki dampak terhadap kesuksesan wirausaha. Suatu jaringan sosial terdiri dari satu seri hubungan formal dan informal antara pelaku 
utama dan orang lain dalam satu lingkaran yang saling mengenal dan menggambarkan saluran dimana wirausahawan tersebut mendapatkan akses kepada sumber penting bagi mulainya suatu bisnis, pertumbuhan, dan kesuksesannya. (Kristiansen et al. 2003)

\subsubsection{Keunggulan bersaing dan posisi pasar strategis}

Keunggulan bersaing adalah kemampuan untuk menghasilkan profit di atas rata-rata pesaing dalam industri. Strategi keunggulan bersaing bertujuan untuk menciptakan posisi yang paling menguntungkan agar dapat bertahan dalam persaingan. Keunggulan bersaing dapat berupa mengambil bentuk harga yang lebih rendah dibandingkan pesaingnya untuk manfaat yang sepadan. Keunggulan biaya atau penyediaan manfaat yang unik lebih dari sekedar mengimbangi harga premium disebut differensiasi. (Porter, 1992: 11-13)

Perbedaan (differensiasi) dipandang sebagai hal yang bermanfaat sepanjang memenuhi criteria, yaitu: penting bagi konsumen, khas/unik, superior/lebih unggul, dapat dikomunikasikan, mendahului/lebih dulu, terjangkau, dan menguntungkan. (Kotler et al. 2012:422-423)

Posisi produk adalah bagaimana produk itu didefinisikan oleh konsumen atas dasar atribut-atributnya yang penting-wadah yang ditempati produk dalam pikiran konsumen berkaitan dengan produk-produk yang bersaing. (Kotler et al. 2012:413). Lebih jauh Kotler et.al (2012:415) juga menyatakan bahwa tugas menetapkan posisi terdiri dari tiga langkah: mengidentifikasi seperangkat keunggulan kompetitif yang mungkin sebagai dasar untuk membangun suatu posisi, memilih keunggulan kompetitif yang tepat dan secara efektif mengkomunikasikan dan menyerahkan posisi yang dipilih ke pasar.

\subsubsection{Customer Orientation/Berorientasi pada Konsumen}

Orientasi pada konsumen muncul bila seluruh kegiatan perencanaan dan pemasaran diawali dan diakhiri oleh kepentingan konsumen. Organisasi yang berorientasi pada konsumen akan selalu menanyakan:

- Kepada siapa kita merencanakan untuk memasarkan suatu produk?

- Dimana mereka berada dan apa yang mereka suka? 
- Apa persepsi yang ada pada mereka sekarang? Apa yang mereka butuhkan dan inginkan?

- Apakah persepsi, keinginan, dan kebutuhan mereka akan berubah di masa yang akan dating pada saat strategi diimplementasikan?

- Seberapa puas konsumen dengan penawaran yang sudah diberikan? (Kotler and Andreasen, 2007: 53).

\subsubsection{Rencana Bisnis}

Rencana bisnis dapat pula berkaitan dengan pengembangan. Smallbone et.al (1995) menekankan bahwa salah satu karakteristik yang membedakan kinerja terbaik perusahaan dari yang lain adalah komitmen pada perubahan. Aktivitas bisnis yang direncanakan dengan baik seperti yang tertuang dalam rencana bisnis akan menghasilkan performa bisnis yang lebih baik pula.

\subsubsection{Komunikasi Pemasaran}

Komunikasi merupakan alat unik yang digunakan oleh pemasar untuk membuat konsumen melakukan tindakan yang dikehendaki oleh pemasar, misalnya untuk melakukan pembelian atau untuk memberikan sumbangan. Bentuk komunikasi beragam, bisa berupa komunikasi verbal tertulis maupun ucapan, visual, atau dapat berbentuk simbolis. (Schiffman et.al, 2000:228). Lebih lanjut Peter\&Olson (2010:273) mengemukakan bahwa pemasar agar ingin konsumennya berkomunikasi dengan dua maksud utama. Mereka ingin konsumen untuk menyediakan informasi pemasaran kepada perusahaan dan memberitahu konsumen potensial untuk tentang produk dan mendorong mereka untuk membelinya.

\subsubsection{Kelebihan Wanita dibanding pria}

Pinky Saptandari (2007) menuliskan bahwa secara psikologis wanita memiliki beberapa kelebihan dibandingkan pria dalam mengembangkan bisnisnya, yaitu: networking yang bagus, kreatif, telaten, dan tidak mudah putus asa.

\subsection{Hasil Penelitian Terdahulu}

Dalam penelitiannya di Inggris, Sandra et.al (1996) menyatakan bahwa aplikasi pemasaran diperlukan juga pada UKM untuk dapat tumbuh dan berkembang, aplikasi disesuaikan dengan kompleksitas masing-masing UKM. Faktor-faktor yang berpengaruh antara lain adalah: fokus pada konsumen, 
keunggulan kompetitif dan pemosisian pasar, komunikasi pemasaran, perencanaan pemasaran, dan perencanaan untuk berkembang.

Indarti (2007) dalam penelitiannya juga menyatakan bahwa faktor-faktor, seperti: latar belakang individu (seperti:usia, jenis kelamin, pengalaman kerja, dan pendidikan), karakteristik UKM (seperti: asal mula perusahaan, lamanya waktu beroperasi, ukuran perusahaan, dan sumber modal), dan variabel kontekstual (terdiri dari: pemasaran, teknologi, akses kepada informasi, kesiapan untuk berwirausaha, jaringan sosial, aspek legalitas, akses kepada modal, dukungan pemerintah, dan rencana bisnis) berpengaruh pada kesuksesan UKM di Yogyakarta.

\section{Metode Penelitian}

\subsection{Daerah Penelitian}

Tempat penelitian ditetapkan di Surabaya. Penentuan tempat penelitian dilakukan dengan sengaja berdasar pertimbangan bahwa:

1. Dapat memberikan kontribusi bagi perkembangan UKM di Surabaya, khususnya bagi UKM yang kurang berkembang agar dapat tumbuh dan berkembang lebih baik dan juga agar menjadi dorongan motivasi bagi wanita di Surabaya, khususnya yang belum bekerja untuk menjadi lebih berani berwirausaha dan lebih produktif.

2. UKM di Surabaya lokasinya dekat dengan peneliti sehingga waktu, tenaga dan biaya dapat diminimalkan.

\subsection{Identifikasi Variabel}

Variabel yang digunakan dalam penelitian ini terdiri dari :

1. Variabel independen atau variabel yang mempengaruhi, yang meliputi : $\mathrm{X}_{1}=$ Akses kepada modal, $\mathrm{X}_{2}=$ Dukungan Pemerintah, $\mathrm{X}_{3}=$ Jaringan Sosial, $\mathrm{X}_{4}=$ Keunggulan bersaing dan pemosisian, $\mathrm{X}_{5}=$ Orientasi pada Konsumen, $\mathrm{X}_{6}=$ Rencana Bisnis, $\mathrm{X}_{7}=$ Komunikasi Pemasaran, $\mathrm{X}_{8}=$ Kelebihan Wanita dibanding Pria.

2. Variabel dependen atau variabel yang dipengaruhi, yaitu Kesuksesan UKM yang dikelola oleh wanita di Surabaya (Y)

\subsection{Definisi Operasional}


Definisi operasional variabel berisi indikator-indikator dari suatu variabel, yang memungkinkan peneliti mengumpulkan data yang relevan untuk variabel tersebut. Definisi operasional variabel dalam penelitian ini dapat dijelaskan sebagai berikut:

I. Variabel Bebas $(\mathrm{X})$, yaitu:

1. Akses kepada Modal.

Merupakan sumber modal yang potensial yang dapat digunakan untuk keperluan usaha.

Indikator yang digunakan adalah:

a. tabungan pribadi, yaitu: tabungan dari pemilik UKM sendiri.

b. pinjaman dari keluarga,/teman, yaitu: pinjaman uang yang diberikan oleh keluarga atau teman.

c. pinjaman dari bank atau institusi keuangan lainnya, yaitu: pinjaman uang yang diberikan oleh bank atau lembaga keuangan lain.

2. Dukungan Pemerintah

Merupakan kemudahan birokrasi dan deregulasi aspek legal bagi para pengelola UKM. Indikator yang digunakan hanya satu, yaitu: kemudahan birokrasi dan kemudahan pengurusan dalam hal-hal yang berkaitan dengan perundang-undangan.

\section{Jaringan Sosial}

Merupakan hubungan formal dan informal antara pengelola/pemilik UKM dan orang lain dalam satu lingkaran yang saling mengenal dan menggambarkan saluran dimana wirausahawan tersebut mendapatkan akses kepada sumber penting bagi mulainya suatu bisnis, pertumbuhan, dan kesuksesannya. Indikator yang digunakan adalah:

a. Perkumpulan/Asosiasi Usaha, yaitu: perkumpulan dengan orangorang yang memiliki jenis usaha yang sama, dapat berupa perkumpulan formal ataupun non formal (tidak tercatat sebagai suatu organisasi resmi).

b. Perkumpulan Hobi, yaitu: perkumpulan dengan orang-orang yang memiliki minat/hobi yang sama. 
c. Perkumpulan Informal, yaitu: perkumpulan yang diikuti yang sifatnya di luar usaha dan hobi, misalnya: pengajian.

4. Keunggulan Bersaing dan Pemosisian

Merupakan kemampuan untuk menghasilkan profit di atas rata-rata pesaing dalam industri. Strategi keunggulan bersaing bertujuan untuk menciptakan posisi yang paling menguntungkan agar dapat bertahan dalam persaingan. Indikator yang digunakan adalah:

a. Inovasi yang dinamis, yaitu : menyesuaikan/mengembangkan produk sesuai dengan pergerakan pasar dengan tetap mempertahankan identitas yang dimiliki oleh UKM.

b. Produk yang unik, yaitu: produk/jasa yang dihasilkan oleh UKM memiliki ciri khas/keunikan yang membedakan dengan produk/jasa yang dihasilkan oleh pesaing.

c. Harga yang kompetitif, yaitu: pemilik/pengelola UKM menawarkan harga yang lebih rendah dibanding pesaing pada produk/jasa dengan kualitas yang sama.

5. Orientasi pada Konsumen.

Merupakan seluruh kegiatan perencanaan dan pemasaran yang diawali dan diakhiri oleh kepentingan konsumen. Indikator yang digunakan adalah:

a. Interpersonal Relationship, yaitu: hubungan yang dijalin dengan para konsumen, yang sifatnya lebih dari sekedar hubungan antara produsen-konsumen.

b. Manajemen Keluhan, yaitu: penanganan yang baik atas keluhan yang disampaikan oleh konsumen.

c. Pelayanan Purna Jual, yaitu: pemberian garansi selama periode tertentu setelah pembelian kepada konsumen.

6. Rencana Bisnis

Merupakan rencana pengembangan usaha untuk waktu yang akan datang. Indikator yang digunakan adalah: 
a. Secara formal, yaitu: rencana bisnis dibicarakan secara formal dan tertulis dalam suatu rapat.

b. Periodik, yaitu: rencana bisnis rutin dibicarakan/dibahas secara periodik, misalnya: mingguan atau bulanan.

c. Ekspansi, yaitu: pemilik/pengelola UKM membuat perencanaan untuk ekspansi atau perluasan usaha di waktu yang akan datang.

\section{Komunikasi Pemasaran}

Merupakan alat unik yang digunakan oleh pemasar untuk membuat konsumen melakukan tindakan yang dikehendaki oleh pemasar. Indikator yang digunakan adalah:

a. Promosi dari mulut ke mulut, yaitu: bentuk promosi yang mengandalkan pada konsumen untuk merekomendasikan produk kepada konsumen potensial.

b. Media cetak,, yaitu: bentuk promosi yang dilakukan dengan memanfaatkan media cetak, misalnya: brosur, pamflet, dan iklan di media cetak.

c. Media Elektronik, yaitu bentuk promosi yang dilakukan dengan memanfaatkan media elektronik, misalnya: radio, televisi, dan via internet.

8. Kelebihan Wanita dibanding Pria dalam Berbisnis.

\subsection{Networking}

Perempuan memiliki keunggulan dalam segi jaringan pemasaran, karena memiliki pergaulan yang luas. Hal ini disebabkan perempuan memiliki kemampuan sosial dan mudah bergaul, sehingga lebih mudah untuk bisa menjaring konsumen.

\subsection{Kreatif}

Perempuan dinilai lebih jeli melihat peluang usaha, dan pandai melihat celah usaha dibandingkan dengan pria. Terkadang hal yang takterpikirkan oleh para pria dan dinilai merupakan langkah bisnis sepele, justru bisa mendatangkan keuntungan dan kesuksesan bila dilakukan oleh kaum perempuan.

\subsection{Telaten}


Perempuan lebih teliti dalam menjalankan bisnis. Hal-hal detail dalam bisnis seperti urusan packaging, labeling, atau hal kecil lainnya, sangat dipikirkan oleh perempuan sehingga membuat produknya menjadi lebih menarik, dan memiliki daya jual yang tinggi.

8.4.Tidak mudah putus asa.

Dalam berbisnis, perempuan dinilai lebih tangguh dan tidak mudah putus asa ketika mengalami kegagalan. Pinky Saptandari (2007).

\subsection{Instrumen Penelitian}

Instrumen pengumpulan data dalam penelitian ini adalah angket/ kuesioner (questionnaire). Kuesioner adalah daftar pertanyaan yang diberikan kepada orang lain dengan maksud agar orang yang diberi tersebut bersedia memberikan responden sesuai dengan permintaan peneliti (Arikunto, Suharsimin, 2010).

Skala pengukuran data bersifat ordinal, di mana angka yang diberikan mengandung pengertian sebagai tingkatan. Ukuran ini tidak memberikan nilai absolut terhadap variabel obyek, tetapi hanya sebagai urutan atau rangking (Umar, Husein, 2013). Penelitian berdasarkan Skala Likert dengan skor yang dipakai 6,5, 4, 3, 2, 1 yang ditetapkan bervariasi sesuai kategori pernyataan setuju:

\begin{tabular}{|l|c|}
\hline \multicolumn{1}{|c|}{ Kriteria } & Skor \\
\hline Sangat setuju & 6 \\
\hline Setuju & 5 \\
\hline Agak setuju & 4 \\
\hline Agak tidak setuju & 3 \\
\hline Tidaksetuju & 2 \\
\hline Sangat tidak setuju & 1 \\
\hline
\end{tabular}

Sumber: Nazir, Mohammad, 2005

Jawaban responden terhadap kuesioner yang diberikan akan dianalisis dengan regresi linier berganda melalui uji secara simultan (uji F) dan uji secara parsial (uji t).

\subsection{Metode Pengambilan Sample}


Populasi adalah kumpulan dari individu dengan kualitas serta ciri-ciri (variabel) yang telah ditetapkan. Sedangkan sampel adalah merupakan bagian dari populasi yang dipillih untuk mewakili populasi (Nazir, Mohammad, 2005).

Pengambilan contoh dilakukan secara acak (random) dengan jumlah contoh minimal $10 \%$ dari populasi yang ada (Singarimbun, Masri dan Effendi, Sofian, 2006).

Populasi dalam penelitian ini adalah seluruh UKM yang dimiliki/dikelola oleh wanita di Surabaya. Jumlah sampel minimum dihitung dengan menggunakan rumus:

$$
\mathrm{n}=\frac{\sigma^{2} z^{2}}{D}
$$

di mana:

$\mathrm{n}$ = jumlah sampel minimum

$\sigma=$ standari deviasi populasi berdasarkan asumsi peneliti

$\mathrm{z}=$ nilai tingkat kepercayaan $(95 \%)$

$\mathrm{D}=$ tingkat ketepatan, yaitu perbedaan antara mean sampel dengan mean populasi

(Malhotra, 2012).

\subsection{Metode Pengumpulan Data}

Dalam penelitian ini, penulis menggunakan cara-cara dalam pengumpulan data antara lain :

1. Studi Kepustakaan

2. Studi Lapangan
a. Observasi
b. Wawancara
c. Penyebaran kuesioner.

\subsection{Metode Analisis Data}

Setelah data terkumpul, maka selanjutnya dilakukan analisis terhadap data yang telah diperoleh tersebut.

Untuk menguji hipotesis yang diajukan digunakan alat analisis regresi linear 
berganda, uji t dan uji F.

\subsubsection{Model Regresi Berganda}

Model regresi berganda dirumuskan sebagai berikut :

$\hat{\mathrm{Y}}_{\mathrm{i}} \quad=\mathrm{a}+\mathrm{b}_{1} \mathrm{X}_{1}+\ldots \ldots \ldots \ldots \ldots+\mathrm{b}_{\mathrm{n}} \mathrm{X}_{\mathrm{n}}$

Dimana :

$\hat{\mathrm{Y}}_{\mathrm{i}} \quad=$ Variabel dependen

$\mathrm{a} \quad=$ Konstanta

$\mathrm{b}_{1} \ldots \mathrm{n}=$ koefisien regresi

$\mathrm{X}_{1 \ldots \mathrm{n}}=$ Variabel independen

(Gujarati, Damodar, 1997).

Model regresi dalam penelitian ini menggunakan satu variabel dependen dan delapan variabel independen dan dirumuskan sebagai berikut :

$\hat{Y}_{\mathrm{i}}=\mathrm{a}+\mathrm{b}_{1} \mathrm{X}_{1}+\mathrm{b}_{2} \mathrm{X}_{2}+\mathrm{b}_{3} \mathrm{X}_{3}+\mathrm{b}_{4} \mathrm{X}_{4}+\mathrm{b}_{5} \mathrm{X}_{5}+\mathrm{b}_{6} \mathrm{X}_{6}+\mathrm{b}_{7} \mathrm{X}_{7}+\mathrm{b}_{8} \mathrm{X}_{8}$

Dimana :

$\hat{\mathrm{Y}}_{\mathrm{i}} \quad=$ Kesuksesan UKM

$\mathrm{a} \quad=$ Konstanta

$\mathrm{b}_{1 \ldots 4}=$ koefisien regresi

$\mathrm{X}_{1}=$ Akses kepada modal

$\mathrm{X}_{2}=$ Dukungan Pemerintah

$\mathrm{X}_{3}$ = Jaringan Sosial

$\mathrm{X}_{4}=$ Keunggulan Bersaing dan Pemosisian

$\mathrm{X}_{5}=$ Orientasi pada Konsumen

$\mathrm{X}_{6}=$ Rencana Bisnis

$\mathrm{X}_{7}=$ Komunikasi Pemasaran

$\mathrm{X}_{8} \quad=$ Kelebihan Wanita

Nilai koefisien regresi dari model regresi linear berganda tersebut dapat digunakan untuk menguji hipotesis ketiga yaitu melihat faktor-faktor yang paling dominan yang mempengaruhi kesuksesan UKM.

\subsubsection{Koefisien Determinasi Berganda $\left(\mathbf{R}^{2}\right)$}

Koefisien Determinasi berganda (multiple coefficient of correlation) digunakan untuk mengetahui berapa besarnya persentase sumbangan variabel 
independen $\left(\mathrm{X}_{1}, \mathrm{X}_{2} \ldots \mathrm{X}_{\mathrm{n}}\right)$ terhadap variasi (naik turunnya) Y secara bersamasama (Supranto, J., 2006).

$\mathrm{R}^{2}$ nilainya antara nol dan satu: $0 \leq \mathrm{R}^{2} \leq 1$. Makin dekat $\mathrm{R}^{2}$ dengan satu, makin cocok garis regresi untuk meramalkan $\mathrm{Y}$. Oleh karena itu $\mathrm{R}^{2}$ dipergunakan sebagai suatu kriteria untuk mengukur cocok tidaknya suatu garis regresi untuk meramalkan variabel dependen Y (goodness of fit criteria) (Supranto, J., 2006).

\subsubsection{Pengujian Hipotesis}

Pengujian hipotesis dilakukan untuk mengetahui pengaruh variabel independen terhadap variabel dependen secara statistik. Pengujian ini dilakukan dengan tingkat keyakinan $95 \%$.

Semua perhitungan untuk menguji hipotesis ini dilakukan dengan menggunakan Program Komputer Statistical Product and Service Solution (SPSS) (Alhusin, Syahri, 2001).

\section{Pengujian Secara Simultan}

Pengujian secara simultan dengan menggunakan statistik uji $\mathrm{F}$ ( F test). Pengujian ini dilakukan untuk menguji hipotesis pertama yaitu mengetahui apakah semua variabel independen secara bersama-sama (simultan) berpengaruh terhadap variabel dependen.

Rumus mencari nilai F hitung (Supranto, J., 2006) adalah :

$$
F_{\text {hitung }}=\frac{\text { Rata-rata kuadrat regresi }}{\text { Rata-rata kuadrat sisa }}
$$

Sedangkan $\mathrm{F}_{\text {tabel }}$ dicari dengan menggunakan tabel $\mathrm{F}$ dengan ketentuan $\mathrm{F}_{0,05(\mathrm{df1})(\mathrm{df} 2)}$ atau $\mathrm{F}_{0,01}(\mathrm{df1})(\mathrm{d} \mathrm{f} 2)$.

Hipotesis yang diajukan dalam penelitian dengan uji simultan ini adalah :

Ho : Tidak ada pengaruh yang nyata variabel independen berupa akses kepada modal, dukungan pemerintah, jaringan sosial, keunggulan bersaing dan posisi pasar strategis, orientasi pada konsumen, rencana bisnis, komunikasi pemasaran, dan kelebihan wanita secara simultan/bersama-sama terhadap variabel dependen kesuksesan Usaha Kecil Menengah (UKM).

Ha : Ada pengaruh yang nyata variabel independen berupa akses kepada modal, dukungan pemerintah, jaringan sosial, keunggulan bersaing dan posisi pasar 
strategis, orientasi pada konsumen, rencana bisnis, komunikasi pemasaran, dan kelebihan wanita secara simultan/bersama-sama terhadap variabel dependen kesuksesan Usaha Kecil Menengah (UKM).

Pengambilan keputusan dilakukan berdasarkan kriteria perbandingan nilai rasio/hitung dengan $\mathrm{F}_{\text {tabel}}$, sebagai berikut :

1. Jika nilai $F_{\text {hitung }}$ lebih kecil daripada $F$ tabel, maka keputusannya adalah menerima Ho. Artinya, secara statistik dapat dibuktikan bahwa semua variabel independen secara bersama-sama (simultan) tidak berpengaruh terhadap perubahan nilai variabel dependen.

2. Jika nilai $F$ hitung lebih besar daripada $F$ tabel, maka keputusannya adalah menolak Ho. Artinya, secara statistik dapat dibuktikan bahwa semua variabel independen secara bersama-sama (simultan) berpengaruh terhadap perubahan nilai variabel dependen. (Firdaus, Muhammad, 2004).

\section{Pengujian Secara Parsial}

Pengujian secara parsial dilakukan dengan menggunakan statistik uji t $(t$ test), Pengujian ini dilakukan untuk menguji hipotesis kedua yaitu mengetahui apakah masing-masing variabel independen secara sendiri-sendiri berpengaruh terhadap variabel dependen.

Rumus untuk mencari nilai t (Gujarati, Damodar, 2011) adalah:

$$
t_{\text {hitung }}=\frac{b}{S_{b}}
$$

Sedangkan $t_{\text {tabel }}$ dicari dengan menggunakan tabel $t$ dengan ketentuan $t_{\propto / 2}$, db=n-k.

Hipotesis yang diajukan dalam penelitian dengan uji parsial ini adalah :

Ho : Tidak ada pengaruh yang nyata variabel independen berupa akses kepada modal, dukungan pemerintah, jaringan sosial, keunggulan bersaing dan posisi pasar strategis, orientasi pada konsumen, rencana bisnis, komunikasi pemasaran, dan kelebihan wanita secara secara sendiri-sendiri terhadap variabel dependen kesuksesan Usaha Kecil Menengah (UKM).

Ha : Ada pengaruh yang nyata variabel independen berupa akses kepada modal, dukungan pemerintah, jaringan sosial, keunggulan bersaing dan posisi pasar strategis, orientasi pada konsumen, rencana bisnis, komunikasi pemasaran, 
dan kelebihan wanita secara secara sendiri-sendiri terhadap variabel dependen kesuksesan Usaha Kecil Menengah (UKM).

Pengambilan keputusan dilakukan berdasarkan kriteria perbandingan nilai $\mathrm{t}$ hitung dengan $t_{\text {tabel}}$, sebagai berikut :

1. Jika nilai $t$ hitung lebih besar daripada $-t$ tabel atau nilai $t$ hitung lebih kecil daripada $+t_{\text {tabel }}\left(-t_{\text {tabel }} \leq t_{\text {hitung }} \leq+t_{\text {tabel }}\right)$, maka keputusannya adalah menerima Ho. Artinya, secara statistik dapat dibuktikan bahwa variabel independen tersebut tidak berpengaruh terhadap perubahan nilai variabel dependen.

2. Jika nilai $t$ hitung lebih besar daripada $+t$ tabel atau $t$ hitung lebih kecil daripada $-\mathrm{t}_{\text {tabel }}\left(\mathrm{t}_{\text {hitung }}<-\mathrm{t}_{\text {tabel }}\right.$ atau $\left.\mathrm{t}_{\text {hitung }}>+\mathrm{t}_{\text {abel }}\right)$ maka keputusannya adalah menolak Ho. Artinya, secara statistik dapat dibuktikan bahwa variabel independen tersebut berpengaruh terhadap perubahan nilai variabel dependen.

Menurut Algifari (2003: 61 - 62) dinyatakan bahwa selain menggunakan uji (uji $\mathrm{F}$ dan uji $\mathrm{t}$ seperti di atas) terhadap koefisen regresi untuk membuat kesimpulan mengenai pengaruh variabel independen terhadap variabel dependen yang terdapat dalam model, baik secara simultan atau sendiri-sendiri, terdapat cara lain yaitu dengan menggunakan angka probabilitas (Sig.) menerima hipotesis nol (Ho). Caranya dengan membandingkan angka probabilitas (Sig.) menerima hipotesis nol dengan tingkat signifikasi yang digunakan $(\alpha)$.

Kriteria pengambilan keputusannya adalah sebagai berikut :

1. Jika angka probabilitas menerima hipotesis nol lebih kecil daripada tingkat signifikasi yang digunakan $(\alpha)$, maka keputusannya adalah menolak hipotesis nol dan menerima hipotesis alternatif (Ha). Artinya variabel independen yang diuji berpengaruh secara signifikan (nyata) terhadap variabel dependen.

2. Jika angka probabilitas menerima hipotesis nol lebih besar daripada tingkat signifikasi yang digunakan $(\alpha)$, maka keputusannya adalah menerima hipotesis nol dan menolak hipotesis alternatif (Ha). Artinya variabel independen yang diuji tidak berpengaruh secara signifikan (nyata) terhadap variabel dependen.

\section{Hasil dan Pembahasan}

\subsection{Deskripsi Hasil Penelitian}


Jumlah responden dalam penelitian ini adalah sebanyak 407 responden yang tersebar dalam 8 wilayah kecamatan, yaitu kecamatan Gunung Anyar, Wonokromo, Tandes, Gubeng, Krembangan, Bubutan, Pabean Cantikan, Sawahan dengan karakteristik responden sebagai berikut:

Tabel 4.1

Karakteristik Responden

\begin{tabular}{|c|c|c|c|c|c|c|c|c|c|c|c|c|c|}
\hline \multirow[b]{2}{*}{ Jumlah } & \multicolumn{5}{|c|}{ Lama Usaha (dalam tahun) } & \multicolumn{4}{|c|}{ Usia } & \multicolumn{4}{|c|}{ Pendidikan } \\
\hline & $1-2$ & $2-4$ & $4-6$ & $6-8$ & $8-10$ & $25<$ & $25-30$ & $30-35$ & 35> & SMA & S1 & S2 & $\begin{array}{l}\text { Akademi } \\
\text { (D1,D3,dll) }\end{array}$ \\
\hline $\begin{array}{l}\text { Dalam } \\
\text { Angka }\end{array}$ & 81 & 168 & 50 & 44 & 62 & 36 & 22 & 16 & 331 & 267 & 46 & 28 & 64 \\
\hline $\begin{array}{l}\text { Dalam } \\
\text { Persen }\end{array}$ & 20 & 41,5 & 12,3 & 10,9 & 15,3 & 8,9 & 5,4 & 4,0 & 81,7 & 65,9 & 11,4 & 6,9 & 15,8 \\
\hline
\end{tabular}

Sumber: Data Primer yang Diolah

\subsection{Uji Validitas dan Reliabilitas Alat Ukur}

Untuk mendapatkan suatu keyakinan tentang sejauh mana alat ukur yang digunakan benar-benar mengukur apa yang diukur, maka perlu dilakukan uji kesahihan item pernyataan. Dalam penelitian ini Uji Validitas dilakukan atas itemitem pernyataan pada kuisioner yaitu dengan jalan menghitung koefisien korelasi Pearson dari tiap-tiap pernyataan dengan skor total yang diperoleh (Djamaludin Ancok dalam Singarimbun, 1989: 132-140). Koefisien korelasi masing-masing item kemudian dibandingkan dengan angka kritis $r$ yang ada pada table kritis $r$ Product Moment sesuai dengan derajat kebebasannya dan tingkat signifikannya. Bila koefisien korelasinya lebih besar dari nilai kritis, maka suatu pernnyataan dianggap valid. Sebaliknya jika koefisien korelasinya lebih kecil dari nilai kritisnya, maka suatu pernyataan dianggap tidak valid/gugur.

Untuk melakukan perhitungan, terlebih dahulu dilakukan pengelompokkan item-item pernyataan ke dalam 8 kelompok, yaitu: item akses kepada modal, item dukungan pemerintah, item jaringan social, item keunggulan bersaing dan pemosisian, item orientasi pada konsumen, item rencana bisnis, item komunikasi pemasaran, dan item kelebihan wanita dibanding pria, sehingga diperoleh nilai total masing-masing kelompok untuk selanjutnya dilakukan perhitungan korelasi. 
Setelah dilakukan pengujian menurut prosedur-prosedur di atas, ternyata seluruh pernyataan item dalam penelitian ini valid. Uji selanjutnya dilakukan untuk mengetahui sejauh mana hasil pengukuran dapat diandalkan kemantapan dan ketepatannya, uji Reliabilitas. Koefisien reliabilitas yang diperoleh pada semua item mendekati niali 1,00 sehingga dapat diambil kesimpulan bahwa perangkat pernyataan yang digunakan untuk mengukur masing-masing variabel dapat diandalkan.

\subsection{Analisis Model dan Pembuktian Hipotesis}

\subsubsection{Analisis Model}

Analisa yang digunakan seperti yang dikemukakan pada bab terdahulu adalah analisa regresi linier berganda dengan Kesuksesan UKM yang dikelola oleh wanita di Surabaya sebagai variabel tergantung. Variabel bebasnya adalah akses kepada modal, dukungan pemerintah, jaringan sosial, keunggulan bersaing dan pemosisian, orientasi pada konsumen, rencana bisnis, komunikasi pemasaran, kelebihan wanita dibanding pria. Perhitungan regresi dan perhitungan lain yang mendukung analisis ini dilakukan dengan menggunakan program SPSS for Windows release 16

\section{Tabel 4.2}

Ringkasan Hasil Analisa Regresi Berganda upaya meningkatkan keberhasilan

UMKM yang dikelola oleh wanita melalui variable kontekstual

\begin{tabular}{|l|l|r|r|r|}
\hline Variabel & Koefisien & Beta & t-observasi & Sig \\
\hline \hline X1 & $-0,129$ & -.117 & -1.863 & .063 \\
\hline X2 & 0,035 & .041 & .699 & .485 \\
\hline X3 & -0.192 & -.198 & -2.546 & .011 \\
\hline X4 & 0,089 & .092 & 1.635 & .103 \\
\hline X5 & 0,039 & .040 & .463 & .643 \\
\hline X6 & 0,361 & .393 & 4.797 & .000 \\
\hline X7 & $-0,160$ & -.169 & -1.673 & .095 \\
\hline X8 & 0,786 & .852 & 8.768 & .000 \\
\hline Konstanta & 0,178 & & 2.785 & \\
\hline F hitung & & $:$ & 379,195 & \\
Standard error of the estimate & $:$ & 0,45318 & \\
R & $:$ & & 0,940 & \\
R square & & & 0,885 & \\
Sumber: Lampiran & $:$ & &
\end{tabular}


Fungsi Linier Berganda dalam penelitian ini adalah:

$\mathrm{Y}=0,178+0$,

$129 \mathrm{X} 1+0,035 \mathrm{X} 2+0,192 \mathrm{X} 3+0,089 \mathrm{X} 4+0,039 \mathrm{X} 5+0,361 \times 6+0,160 \mathrm{X} 7+0,786 \mathrm{X} 8+\mathrm{e}$

Keterangan:

Y : Peningkatan Keberhasilan UMKM yang dikelola oleh wanita.

X1 : Akses kepada modal.

X2 : Dukungan Pemerintah

X3 : Jaringan Sosial

X4 : Keunggulan Bersaing dan Pemosisian

X5 : Orientasi pada Konsumen

X6 : Rencana Bisnis

X7 : Komunikasi Pemasaran

X8 : Kelebihan Wanita

4.4.2. Pembuktian Hipotesis

4.4.2.1.Pembuktian Hipotesis Pengaruh Masing-Masing Variabel Secara Individu

Dalam pengujian pengaruh masing-masing variabel atau secara parsial ini setelah $\mathrm{t}$ observasi diperoleh kemudian dibandingkan dengan nilai $\mathrm{t}$ dari tabel $\mathrm{t}$ dengan tingkat keyakinan $95 \%$. Untuk jelasnya dapat dilihat pada tabel berikut ini:

Tabel 4.3

Analisa Uji t

\begin{tabular}{|l|r|l|c|}
\hline Variabel & $\begin{array}{l}\text { Nilai t } \\
\text { observasi }\end{array}$ & $\begin{array}{l}\text { Nilai t } \\
\text { table }\end{array}$ & Keterangan \\
\hline \hline X1 & 1.863 & 1,986 & Tidak Signifikan \\
\hline X2 & .699 & 1,986 & Tidak Signifikan \\
\hline X3 & 2.546 & 1,986 & Signifikan \\
\hline X4 & 1.635 & 1,986 & Tidak Signifikan \\
\hline X5 & .463 & 1,986 & Tidak Signifikan \\
\hline X6 & 4.797 & 1,986 & Signifikan \\
\hline X7 & 1.673 & 1,986 & Tidak Signifikan \\
\hline X8 & 8.768 & 1,986 & Signifikan \\
\hline
\end{tabular}

Sumber: Lampiran 
Dari tabel 4.3 dapat dilihat $\mathrm{t}$ observasi variabel X1 lebih kecil dari t tabel pada pengujian 2 arah $\alpha / 2$, maka dapat dikatakan hipotesa nol (Ho) diterima, artinya hipotesis yang menyatakan bahwa akses kepada modal tidak memiliki pengaruh terhadap kesuksesan UMKM yang dikelola wanita diterima, berarti bahwa akses kepada modal tidak memiliki pengaruh terhadap terhadap kesuksesan UMKM yang dikelola wanita.

Tabel 4.3 juga menunjukkan t observasi variabel X2 lebih kecil dari t tabel pada pengujian 2 arah $\alpha / 2$, maka dapat dikatakan hipotesa nol (Ho) diterima, artinya hipotesis yang menyatakan bahwa dukungan pemerintah tidak berpengaruh terhadap kesuksesan UMKM yang dikelola oleh wanita diterima, berarti bahwa dukungan pemerintah tidak memiliki pengatuh terhadap kesuksesan UMKM yang dikelola oleh wanita.

Dari tabel 4.3 terlihat bahwa t observasi variabel X3 lebih besar dari t tabel pada pengujian 2 arah $\alpha / 2$, maka dapat dikatakan hipotesa nol (Ho) ditolak, artinya hipotesis yang menyatakan bahwa jaringan sosial tidak memiliki pengaruh terhadap kesuksesan UMKM yang dikelola oleh wanita ditolak. Ho ditolak, sehingga Ha diterima, berarti bahwa jaringan sosial memiliki pengaruh terhadap kesuksesan UMKM yang dikelola oleh wanita.

Tabel 4.3 menunjukkan t observasi variabel X4 lebih kecil dari t tabel pada pengujian 2 arah $\alpha / 2$, maka dapat dikatakan hipotesa nol (Ho) diterima, artinya hipotesis yang menyatakan bahwa keunggulan bersaing dan pemosisian tidak memiliki pengaruh terhadap kesuksesan UMKM yang dikelola oleh wanita diterima.

Dari tabel 4.3 dapat dilihat bahwa t observasi variabel X5 lebih kecil dari t tabel pada pengujian 2 arah $\alpha / 2$, maka dapat dikatakan hipotesa nol (Ho) diterima, artinya hipotesis yang menyatakan bahwa Orientasi pada Konsumen tidak memiliki pengaruh terhadap kesuksesan UMKM yang dikelola oleh wanita diterima, berarti bahwa Orientasi pada Konsumen tidak memiliki pengaruh terhadap kesuksesan UMKM yang dikelola oleh wanita.

Tabel 4.3 menunjukkan bahwa t observasi variabel X6 lebih besar dari t tabel pada pengujian 2 arah $\alpha / 2$, maka dapat dikatakan hipotesa nol (Ho) ditolak, 
artinya hipotesis yang menyatakan bahwa Rencana Bisnis tidak memiliki pengaruh terhadap terhadap kesuksesan UMKM yang dikelola oleh wanita ditolak. Ho ditolak, sehingga Ha diterima, berarti bahwa Rencana Bisnis memiliki pengaruh terhadap kesuksesan UMKM yang dikelola oleh wanita.

Dari tabel 4.3 juga dapat dilihat bahwa t observasi variabel X7 lebih kecil dari t tabel pada pengujian 2 arah $\alpha / 2$, maka dapat dikatakan hipotesa nol (Ho) diterima, artinya hipotesis yang menyatakan komunikasi pemasaran tidak memiliki pengaruh terhadap kesuksesan UMKM yang dikelola oleh wanita diterima, berarti bahwa komunikasi pemasaran tidak memiliki pengaruh terhadap kesuksesan UMKM yang dikelola oleh wanita.

Tabel 4.3 menunjukkan bahwa t observasi variabel X8 lebih besar dari t tabel pada pengujian 2 arah $\alpha / 2$, maka dapat dikatakan hipotesa nol (Ho) ditolak, artinya hipotesis yang menyatakan bahwa Kelebihan Wanita tidak memiliki pengaruh terhadap terhadap kesuksesan UMKM yang dikelola oleh wanita ditolak. Ho ditolak, sehingga Ha diterima, berarti bahwa Kelebihan Wanita memiliki pengaruh terhadap kesuksesan UMKM yang dikelola oleh wanita.

Hasil analisa regresi secara parsial seperti yang dikemukakan di atas menunjukkan bahwa Jaringan Sosial dengan nilai t observasi sebesar 2,546, Rencana Bisnis dengan nilai t observasi sebesar 4, 797, dan terakhir Kelebihan Wanita dengan nilai t observasi sebesar 8,768 berpengaruh terhadap kesuksesan UMKM yang dikelola oleh wanita.

Hasil penelitian tersebut sesuai dengan beberapa penelitian sebelumnya., sebagaimana yang dituliskan oleh Adawiyah (2017) bahwa untuk mempercepat pertumbuhan dan pengembangan usaha kecil dan menengah, maka beberapa hal perlu dilakukan, yaitu: pengembangan jaringan sosial, para akademisi dengan program inkubasi bisnisnya perlu menyasar pengusaha kecil; ketiga, para pengusaha kecil perlu mendaftarkan diri sebagai anggota jejaring bisnis formal (misal menjadi anggota asosiasi tertentu) sebagai bagian dari strategi pengembangan usaha mereka. Melalui program tersebut diharapkan para pengusaha kecil mampu membangkitkan usaha mereka ke level yang lebih tinggi. Putri (2017) juga menyebutkan bahwa pelaku usaha yang berhasil dalam menjalankan usahanya 
memiliki jaringan sosial secara mikro yaitu dalam hal produksi dan pemasaran yaitu dengan pelaku usaha lainnya (penyedia bahan baku) dan juga dengan pembeli (pelanggan). Jaringan mikro ini ada dalam proses produksi dan pemasaran. Selain itu, pelaku usaha juga memiliki jaringan secara makro, baik dengan Dinas Koperasi dan UMKM, dengan pihak bank, IWAPI, maupun dengan pihak lainnya seperti perguruan tinggi, LIPI, maupun instansi lainnya yang terkait.

Rencana bisnis secara parsial juga berpengaruh terhadap keberhasilan UMKM. Hal ini juga didukung oleh Trisninawati (2014) dalam penelitiannya yang menyatakan bahwa rencana bisnis berperan sebagai alat untuk meningkatkan keberhasilan usaha dengan cara memiliki visi dan tujuan bisnis, berani mengambil risiko dan uang, mampu menyusun perencanaan usaha, mengorganisir sumber daya, dan implementasinya, sanggup bekerja keras, mampu membangun hubungan dengan pelanggan. Majamal (2017) dalam penelitiannya juga menyebutkan bahwa di Negara berkembang, perencanaan bisnis perlu dilakukan agar UMKM dapat tumbuh dan berkembang. Pemilik usaha maupun pengelola usaha wajib memiliki pengetahuan yang cukup tentang manajemen dan kewirausahaan.

Faktor lain yang secara parsial memiliki pengaruh terhadap keberhasilan UMKM yang dikelola wanita adalah kelebihan wanita dibandingkan pria. Uddin (2017) juga menuliskan bahwa otak wanita dan pria berbeda dalam beberapa hal, misal pada bagian yang bertanggung jawab terhadap kemampuan untuk mengatur kemarahan, pada wanita bagian ini berukuran lebih besar daripada pria sehingga wanita dapat lebih baik dalam mengendalikan amarahnya. Hal inilah yang membuat wanita lebih telaten dalam mengelola usaha. Pada bagian yang bertanggung jawab terhadap penyerapan informasi dan bagaimana menyikapinya,otak wanita juga memiliki ukuran yang lebih besar daripada pria pada bagian ini sehingga wanita bisa lebih mudah menyerap informasi dan kemudian mengolahnya untuk dipergunakan sesuai dengan kepentingannya. Lebih jauh dapat dikatakan karena hal inilah maka wanita menjadi lebih luwes dalam mengembangkan jaringan sosialnya untuk mengembangkan usaha. Demikian juga pada bagian otak yang berfungsi untuk menggunakan kata-kata dalam mengekspresikan obyek tertentu, wanita memiliki bagian yang lebih besar dibanding pria. 
Pinky Saptandari (2007) juga menuliskan beberapa yang menjadi kelebihan wanita dalam menjalankan usaha, yaitu:

- Networking

Perempuan memiliki keunggulan dalam segi jaringan pemasaran, karena memiliki pergaulan yang luas. Hal ini disebabkan perempuan memiliki kemampuan sosial dan mudah bergaul, sehingga lebih mudah untuk bisa menjaring konsumen.

- Kreatif

Perempuan dinilai lebih jeli melihat peluang usaha, dan pandai melihat celah usaha dibandingkan dengan pria. Terkadang hal yang takterpikirkan oleh para pria dan dinilai merupakan langkah bisnis sepele, justru bisa mendatangkan keuntungan dan kesuksesan bila dilakukan oleh kaum perempuan.

- Telaten

Perempuan lebih teliti dalam menjalankan bisnis. Hal-hal detail dalam bisnis seperti urusan packaging, labeling, atau hal kecil lainnya, sangat dipikirkan oleh perempuan sehingga membuat produknya menjadi lebih menarik, dan memiliki daya jual yang tinggi.

- Tidak mudah putus asa.

Dalam berbisnis, perempuan dinilai lebih tangguh dan tidak mudah putus asa ketika mengalami kegagalan.

\subsubsection{Pengujian Hipotesis Pengaruh Variabel Bebas Secara Bersama}

Dari tabel 4.2 diketahui bahwa nilai F observasi sebesar 379,195 sedangkan F tabelnya yakni pada $\mathrm{F}_{(8 / 405: 0,05)}$ adalah sebesar 2,04. Berarti $\mathrm{F}$ hitung lenih besar dari $\mathrm{F}$ tabelnya, sehingga Ho ditolak dan Ha diterima artinya secara bersama variabel bebas, yang terdiri dari: Akses kepada modal, Dukungan Pemerintah, Jaringan Sosial, Keunggulan Bersaing dan Pemosisian, Orientasi pada Konsumen, Rencana Bisnis, Komunikasi Pemasaran, dan Kelebihan Wanita mempunyai pengaruh yang signifikan terhadap kesuksesan UMKM yang dikelola wanita.

Hasil penelitian terdahulu oleh Indarti (2007) menunjukkan hasil bahwa variabel pemasaran, teknologi, akses kepada informasi, kesiapan untuk berwirausaha, jaringan sosial, aspek legalitas, akses kepada modal, dukungan pemerintah, dan rencana bisnis) berpengaruh pada kesuksesan UKM. Terdapat 
beberapa kesamaan variabel yang digunakan dalam penelitian ini, yaitu variabel jaringan sosial, akses kepada modal, dukungan pemerintah dan rencana bisnis, sehingga menunjukkan bahwa di daerah lain dan pada UKM secara umum variabel tersebut secara bersama memiliki pengaruh terhadap kesuksesan UKM.

Penelitian ini lebih menitikberatkan pada UMKM yang dikelola oleh wanita, sehingga didalamnya ditambahkan variabel lain berupa kelebihan wanita dibandingkan pria secara psikologi dalam mengelola usaha. Variabel lain yang ditambahkan adalah keunggulan bersaing dan pemosisian, orientasi pada konsumen dan komunikasi pemasaran. Hal ini menunjukkan keterbaruan dari penelitian ini dibandingkan dengan penelitian sebelumnya.

\section{Kesimpulan}

1. Faktor-faktor berupa akses kepada modal, jaringan sosial, keunggulan bersaing dan posisi pasar strategis, orientasi pada konsumen, komunikasi pemasaran, dan kelebihan wanita dibandingkan pria secara bersama memiliki kontribusi pada keberlangsungan dan kesuksesan Usaha Mikro Kecil Menengah (UMKM) yang dikelola oleh wanita.

2. Faktor rencana bisnis, Jaringan Sosial, dan Kelebihan Wanita dibanding Pria adalah variable yang secara parsial memiliki kontribusi pada keberlangsungan UMKM yang dikelola oleh wanita.

3. Kesuksesan UMKM bisa dilihat dari peningkatan omzet dan margin usaha, penambahan asset, dan penambahan jumlah tenaga kerja pada tiap periode.

\section{Saran}

1. Rencana bisnis termasuk rencana ekspansi secara formal dan periodik harus dibuat agar dapat menjadi acuan bagi UMKM untuk target ke depan.

2. Pengembangan jaringan sosial, baik secara formal maupun non formal, perlu untuk selalu dilakukan agar UMKM yang dikelola wanita dapat terus tumbuh dan berkembang. 


\section{DAFTAR PUSTAKA}

Laporan Tahunan Bank Indonesia 2015

Laporan Tahunan Kementerian Koperasi Dan Ukm Tahun 2015

USAID dan IFC Indonesian Market Research Study. 2016. Sandra Hogarth-Scott, Kathryn Watson, and Nicholas Wilson (1996), Do Small Business have to Practice Marketing ti survive and Grow? Marketing Intelligence\&Planning, 14/1:6-18.

Indarti, Nurul (2007), Enterpreneurship dan Usaha Kecil Menengah di Indonesia, Ardana Media, Yogyakarta.

Kusuma, Pratita V (2013), Resipatory Library Universitas Indonesia.

Novie Noordiana R Y (2017), Faktor-Faktor Yang Memiliki Kontribusi Pada Keberlangsungan Dan Kesuksesan UMKM Yang Dikelola Oleh Kalangan Usia Muda, Jurnal Relasi Edisi XIII Vol. 1, STIE Mandala Jember.

Abrar-ul-haq, Muhammad, Mohd Razani Mohd Jali and Gazi Md Nurul Islam (2015), Factors Affecting Small and Medium Enterprises (SMES) Development in Pakistan, American-Eurasian J. Agric. \& Environ. Sci., 15 (4): $546-552$.

Goyal, Preeti, Vanita Yadav (2014), To Be Or Not To Be A Woman Entrepreneur In A Developing Country? Psychosociological Issues in Human Resource Management Volume 2(2), 2014, pp. 68-78, ISSN 2332-399X

Laporan Tahunan Departemen Koperasi dan Usaha Kecil Menengah dan BPS 2012 Kotler, Philip dan Armstrong, Gary. (2012). Principles of Marketing. New Jersey:

Prentice Hall.

Kotler, Philip, Kevin Lane Keller. (2012). Marketing Management, 14th Edition United States of America

Kotler, P. and Andreasen, A. (2007), Strategic Marketing for Nonprofit Organizations, Prentice-Hall, Englewood Cliffs, NJ.

Peter, J. Paul\&Jerry C. Olson (2010), Perilaku Konsumen dan Strategi Pemasaran, Erlangga, Jakarta.

Saptandari, Pinky (2007) Modul, Pendidikan Karakter \& Pekerti Bangsa Responsif Gender Kementerian Negara Pemberdayaan Perempuan. 
Hermawan, Asep, Prof, Dr, M. Sc (2009), Penelitian Bisnis, Paradigma Kuantitatif, Grasindo, PT Gramedia Widiasarana Indonesia,Jakarta.

Arikunto, Suharsimin (2010), Manajemen Penelitian, Penerbit Rineka Cipta, Jakarta.

Nazir, Mohammad ( 2005), Metode Penelitian, Ghalia Indonesia, Jakarta.

Gujarati, Damodar (2011), Ekonometrika Dasar, Penerbit Erlangga, Jakarta.

Wiwiek Rabiatul Adawiyah (2017), Strategi Pengembangan Jejaring Bisnis Kewirausahaan Pedesaan, Jurnal LPPM Universitas Jenderal Soedirman Purwokerto, Volume 7 No. 1.

Zeni Eka Putri (2018), Pemanfaatan Jaringan Sosial dalam Pengembangan Usaha oleh Pelaku Umkm (Studi Kasus: 8 Pelaku UMKM pada Sentra Makanan Rendang di Kelurahan Sungai Durian, Kecamatan Lamposi Tigo Nagari, Kota Payakumbuh), Jurnal Sains, Sosial dan Humaniora Volume 2 No. 1.

Trisninawati 1),Irwan Septhayuda2), (2014), Peran Rencana Bisnis Sebagai Alat Untuk Meningkatkan Keberhasilan Usaha ( Studi Kasus Umkm Di Bawah Binaan Bina Darma Entrepreneurship Center (BDEC), Sustainable Competitive Advantage (SCA) Vol.4 No.1

Nomsa Sisi Majamal \& Tebogo Israel ‘Teddy’ Magang (2017), Strategic Planning In Small And Medium Enterprises (Smes): A Case Study Of Botswana SMEs, Journal Of Management And Strategy Vol. 8, No. 1

MD, Sahab Uddin (2017), Brain Chemistry and Sex Differences: Are Male and Female Brains Really Varied? Journal of Neuroscience and Neuropharmacology Volume $4 \cdot$ Issue $1 \cdot 1000117$ 